\title{
PIDANA MATI DALAM PERSPEKTIF HUKUM PIDANA DAN HUKUM PIDANA ISLAM
}

\author{
Roni Efendi \\ Fakultas Syariah IAIN Batusangkar \\ J1. Jenderal Sudirman No. 137, Lima Kaum Batusangkar \\ e-mail: rhonieeffendy@gmail.com
}

\begin{abstract}
Debatable of the death penalty actually based on the issue of justice, bumanity and the prevention of the possibility of crime. The reasons for the rejection of the death penalty are not justified in the view of life as well as humanitarian factors and the imposition of capital punishment will not be able to prevent crime and reduce crime rates. But for those who agree with the imposition of capital punishment because of the sense of justice and peace that is in the community. The portrait is just a glimpse of the issue that colored the discourse on the pros and cons of the existence of capital punishment. Between the retensionist and the abilitionist against true the death penalty has an argument each based on his theoretical framework and norms. Indonesia as one of the countries with the European Continental legal system still apply the death penalty in punishment system beside Saudi Arabia with qhisash which applid in Islamic Law system. Both countries have a legal standing built on the meta norms, their theories and philosophies each of course has its own urgency to be discussed in the midst of countries that condemn the existence of capital punishment. Here's an article that analyzes comparative relation to the application of the death penalty in both countries that embraces the different legal system, from this comparative study will contribute thoughts in the reform of criminal law in Indonesia.
\end{abstract}

Kata kunci: pidana mati, hukum pidana, hukum pidana Islam

\section{PENDAHULUAN}

P

erbedaan

paradigma

dalam memaknai eksistensi pidana mati dalam berbagai sistem hukum yang berlaku di dunia, Belanda sebagai negara pewaris Wetboek van Strafrech (WvS) kepada Indonesia sudah menghapus pidana mati dari sistem pemidanaannya dengan dasar hukum dan teori yang telah diungkapkan di atas. Namun dari sekian banyak negara yang sudah tidak mengakomodir pidana mati, masih terdapat beberapa negara dengan sistem hukum civil law yang masih mempertahankan eksistensi pidana mati seperti negara Indonesia. Sementar di belahan dunia yang berbeda, Arab Saudi dengan sistem hukum Islam, juga tercatat sebagai salah satu negara yang masih mempertahankan pidana mati.

Indonesia pidana mati diatur dalam Kitab Undang-Undang Hukum Pidana (KUHP) sebagai kodifikasi hukum pidana positif yang berasal dari WvS, diberlakukan berdasarkan asas konkordansi. WvS berlaku di Indonesia sejak 1 Januari 1918 dengan Stb 1915 Nomor 732. Setelah Indonesia merdeka WvS tetap diberlakukan berdasarkan Undang-Undang Nomor 1 Tahun 1946 dan berdasarkan undang-undang ini Kitab Undang-Undang Hukum Pidana mendapatkan nama KUHP yang 
kemudian diberlakukan kembali untuk seluruh wilaya negara Kesatuan Republik Indonesia berdasarkan Undang-Undang Nomor 73 Tahun 1958. (Agustina, 2015: 32)

Pada ketentuan ini, pidana mati ditetapkan sebagai salah satu jenis pidana pokok yang tertuang dalam Pasal 10 KUHP. Pasal 10 KUHP tersebut adalah sebagai berikut: (Kitab Undang-undang Hukum Pidana dan Kitab Undangundang Hukum Acara Pidana, 2006: 5)

Pasal 10: Pidana terdiri atas:

1. Pidana Pokok
a. Pidana mati
b. Pidana penjara
c. Pidana kurungan
d. Pidana denda
e. Pidana tutupan

2. Pidana Tambahan

a. Pencabutan hak-hak tertentu

b. Perampasan barang-barang tertentu

c. Pengumuman putusan hakim.

Pasal tersebut menegaskan bahwa pidana mati merupakan jenis pidana yang berada pada urutan pertama dalam hirarki pidana pokok. Di samping KUHP, banyak terdapat peraturan di luar KUHP yang mengatur tentang pidana mati di luar KUHP yang dikenal dengan pidana khusus, di antaranya Undang-Undang Tentang Tindak Pidana Terorisme (UU No 15 Tahun 2003), Undang-Undang Tentang Pengadilan Hak Asasi Manusia (UU No 26 Tahun 2000), Undang-Undang Tentang Psikotropika (UU No 5 Tahun 1997) dan Undang-Undang Nomor 35 Tahun 2009 Tentang Narkotika.

Sementara dalam sistem hukum yang berbeda, Arab Saudi juga sebagai salah satu negara yang saat ini masih memberlakukan pidana mati dengan istilah qhisash. Qhisash merupakan hukuman yang telah disyari'atkan berdasarkan Alquran, sunnah dan ijma'. Qhisash secara bahasa artinya adalah menelusuri jejak. Pengertian tersebut digunakan untuk arti hukuman, karena orang yang berhak atas qhisash mengikuti dan menelusuri jejak tindak pidana dari pelaku. Qhisash juga dapat diartikan sebagai keseimbangan dan kesepadanan. Sehingga qhisash dapat didefenisikan memberikan balasan kepada pelaku tindak pidana sesuai dengan perbuatannya. (Zuhaili, 1989: 261)

Sebagai sistem hukum yang berbeda, pemberlakuan pidana mati di Indonesia dan qhisash yang berlaku di Arab Saudi Studi akan menarik untuk diperbandingkan. Perbandingan hukum pidana pada dasarnya memperbandingkan berbagai sistem hukum yang ada. Dalam Black's Law Dictionary yang dikutip oleh Barda Nawai Arief perbandingan hukum didefinisikan: "Comparative Jurisprudence is the study of the principles of legal science by the comparison of various systems of law". (Barda Nawawi Arief, 2003: 3)

Dalam hal ini yang akan diperbandingkan adalah dua atau lebih dari sistem hukum yang berbeda. Yakni pidana mati dalam hukum pidana positif Indonesia yang berasal dari Civil Law System atau Eropa Continental. Civil law atau sistem hukum Eropa Continental merupakan sistem hukum yang diturunkan dari Romawi Kuno dan pertama kali diterapkan di Eropa berdasarkan jus civile. Prinsip utama yang menjadi dasar sistem hukum Eropa Continental itu ialah hukum memperoleh kekuatan mengikat, karena diwujudkan dalam peraturan-peraturan yang berbentuk undang-undang dan tersusun 
secara sistematik di dalam kodifikasi atau kompilasi tertentu. Prinsip dasar ini dianut mengingat bahwa nilai utama yang merupakan tujuan hukum adalah kepastian hukum. Kepastian hukum hanya dapat diwujudkan kalau tindakantindakan hukum manusia dalam pergaulan hidup diatur dengan peraturan-peraturan hukum yang tertulis. (Mahmud, 2009: 286)

Kemudian menganalisa ketentuan pidana mati dalam sistem hukum pidana Islam (Muslich, 2006: 3) yang dianut Negara Arab Saudi. Hukum pidana Islam Atau Figh Jinayah merupakan bagian dari syari'at Islam yang berlaku sejak diutusnya Rasulullah SAW. Oleh karenanya, pada zaman Rasulullah dan Khulafaur Rasyidin, hukum pidana Islam berlaku sebagai hukum publik. Yaitu hukum yang diatur dan diterapkan oleh pemerintah selaku penguasa yang sah atau ulil amri.

Karena pidana mati yang dianut kedua sistem hukum tersebut berorientasi pada upaya pembalasan kepada terpidana dan sebagai tindakan prevensi umum. Namun tidak tertutup kemungkinan pidana mati dalam hukum pidana Islam bisa berubah menjadi pidana lain yaitu pidana penjara seumur hidup, sama halnya dengan qhisash yang dapat berubah menjadi pidana diyat serta $t a^{\prime} z i r$.

Ketertarikan penulis untuk memperbandingan pidana mati dari kedua sistem hukum yang berbeda dikarenakan hingga saat ini pidana mati merupakan topik yang selalu kontroversi untuk dibahas. Kontroversi ini disebabkan oleh permasalahan yang sangat kompleks dalam pelaksanaan pidana mati tersebut. Permasalahan yang satu saling berkaitan dengan permasalahan yang lain. Bahkan, masalah yang sama bisa ditinjau dari sudut pandang yang berbeda. Demikian sebaliknya, masalah yang sebenarnya berbeda bisa menjadi masalah yang sama karena ditinjau dari sudut pandang yang sama.

\section{METODE PENELITIAN}

\section{Pendekatan Masalah}

Dalam penelitian ini, Penulis menggunakan metode penelitian hukum normatif, yang mencakup tentang asasasas hukum. Selain itu penelitian ini juga mengkaji dan meneliti peraturan perundang-undangan. (Soekanto, 1986: 15). Yakni peraturan perundangundangan terkait pelaksanaan pidana mati dengan meta norma yang berasal dari kajian filsafat dan teori hukum. Sehingga ditemukan masalah dan solusi mendasar terkait dengan kedudukan masa tunggu eksekusi bagi terpidana mati dalam sistem pemidanaan. Penelitian hukum normatif akan bertitik tolak pada bahan pustaka atau data sekunder, dengan cakupan bahan hukum primer, sekunder dan tersier. (Soekanto, 1986: 52)

Metode penelitian hukum normatif adalah metode atau cara yang dipergunakan di dalam penelitian hukum yang dilakukan dengan cara meneliti bahan pustaka yang ada. (Soekanto dan Mamudji, 2009: 13). Dengan kata lain penelitian ini penelitian kepustakaan (Library Reseach) artinya penelitian ini dilakukan dengan membaca karya-karya yang terkait dengan persoalan yang akan dikaji kemudian memuat kajian tentang penelitian. (Zed, 2007: 3) 


\section{Sifat Penelitian}

Penelitian pada dasarnya merupakan tahapan untuk mencari kembali sebuah kebenaran. Sehingga akan dapat menjawab pertanyaan yang muncul tentang suatu objek penelitian. (Sugono, 2001: 29) Penelitian ini bersifat deskriptif yaitu penelitian yang dilakukan untuk menguraikan objek penelitiannya, atau penelitian yang bertujuan untuk mendeskripsikan tentang sesuatu hal di daerah tertentu dan pada saat tertentu. (Waluyo, 2002: 8) Maka sifat penelitian yang penulis gunakan adalah penelitian hukum deskriptif (descriptive legal study) berupa pemaparan dan bertujuan untuk memperoleh gambaran lengkap tentang penerapan hukum.

Dalam hal sifat penelitian, penulis lebih cenderung menggunakan tipe reform-oriented research, yang menurut Hitchinson sebagai research which intensively evaluates the adequacy of exsiting rules and which recommends changes to any rules found wanting. (Muhammad, 2004: 52)

Pilihan pendekatan dalam penelitian ini adalah menggunakan pendekatan penelitian hukum doktrinal (doctrinal legal research). Dengan pendekatan ini, berarti penelitian akan mengkaji hukum sebagai sebuah sistem yang normatif. (Hoecke, 2011: 3) Sebagai sebuah sistem yang normatif maka hukum tidak dapat dipandang hanya sebagai aturan tertulis saja, semacam undang-undang, melainkan keseluruhan asas yang ada dan mendasarinya maupun bentuk lain dari kaidah hukum yang tidak tertulis atau ketika dilaksanakan (in conreto).

Dalam konsep teori, pertanyaan penelitian diarahkan guna melihat kembali rasionalisasi dan asumsi dasar dalam preoses pelaksanaan pidana mati di Indonesia. Untuk menjelaskan hal tersebut, penulis perlu menggali teoriteori dalam ilmu hukum yang dapat menjelaskan hal tersebut.

\section{Sumber Bahan Hukum}

Karena penelitian ini merupakan penelitian hukum normatif maka sumber hukum yang digunakan adalah sumber hukum primer dan sumber hukum sekunder, yaitu:

1. Bahan Hukum Primer, yaitu berasal dari peraturan perundang-undangan.

2. Bahan Hukum Sekunder, yaitu bahan yang memberikan penjelasan mengenai bahan hukum primer. (Soekanto dan Mamudji, 2009: 13) Bahan hukum sekunder berasal dari buku-buku teks yang berisi prinsip-prinsip hukum dan pandangan-pandangan para sarjana. (Hanitijo, 1993: 43)

3. Bahan hukum tersier, merupakan bahan hukum yang memberikan petunjuk maupun penjelasan terhadap bahan hukum primer dan bahan hukum sekunder. (Soekanto, 2006: 61) Seperti kamus hukum, ensiklopedia, indeks kumulatif, Kamus Besar Bahasa Indonesia, dan internet.

\section{Metode Pengumpulan Data}

Sebagaimana ciri dari penelitian hukum normatif, maka metode pengumpulan data dapat dilakukan dengan studi kepustakaan (library research), maksudnya adalah jika data yang diperlukan untuk menjawab masalah penelitian terdapat dalam bahan pustaka, maka kegiatan pengumpulan data itu disebut dengan literatur study. (Adi, 2004: 72) Selanjutnya dapat 
dilakukan dengan studi dokumen terhadap literatur yang berkaitan dengan pelaksanaan pidana mati dalam sistem pemidanaan.

\section{Pengolahan Data dan Analisis Data}

\section{Pengolahan Data}

Pengolahan data adalah kegiatan merapikan hasil pengumpulan data di lapangan, yaitu dengan cara menyeleksi atas dasar reabilitas dan validitasnya. (Suryabrata, 2006: 40) Data yang telah didapat dilakukan edditing yaitu meneliti kembali terhadap catatan-catatan, berkasberkas, informasi yang dikumpulkan oleh pencari data yang diharapkan akan dapat meningkatkan mutu kehandalan (reabilitas) yang hendak dianalisis. (Amiruddin dan Asikin, t,th.: 168)

Setelah lengkap data yang penulis kumpulkan dari lapangan, penulis melakukan pengolahan data ketahap berikutnya yaitu cording yaitu proses untuk mengklasifikasikan jawabanjawaban responden berdasarkan kriteria yang ditetapkan. (Sugono, 2001: 126)

\section{Analisis Data}

Penulis melakukan analisis data dengan menggunakan metode analisis kualitatif yaitu analisis yang dilakukan tidak dengan menggunakan angka-angka atau rumus statistik, melainkan dengan menggunakan kata-kata atau uraian kalimat dengan melakukan penilaian berdasarkan peraturan perundangundangan, teori atau pendapat ahli, serta logika sehingga dapat ditarik kesimpulan yang logis dan merupakan jawaban dari permasalahan. Kemudian penulis juga menggunakan analisis isi (content analisis) yaitu teknik apapun yang digunakan untuk menarik kesimpulan melalui usaha menemukan karakteristik pesan dan dilakukan secara objektif dan sistematis. (Soejono dan Abdurrahman, 2003: 16)

\section{PEMBAHASAN}

\section{Kedudukan Pidana Mati dalam Sistem Hukum Pidana di Indonesia}

\section{Pidana Mati dalam Sistem Pemidanaan}

Kata pidana mati menurut Kamus Umum Bahasa Indonesia pidana mati berasal dari kata "pidana" dan "mati". (Poerwodarminto, 1983: 750) Pidana berasal dari kata straf (Belanda), yang pada dasarnya dapat dikatakan sebagai suatu penderitaan atau nestapa yang sengaja dikenakan atau dijatuhkan kepada seseorang yang telah terbukti bersalah melakukan suatu tindak pidana. (Muladi dan Arif, 2005: 1) Sedangkan kata "mati" mempunyai arti kehilangan nyawa. (Poerwodarminto, 1983: 750)

Bentuk pidana ini merupakan pidana yang dilaksanakan dengan merampas jiwa seseorang yang melanggar ketentuan undang-undang. Pidana ini juga merupakan pidana tertua dan paling kontroversial dari berbagai bentuk pidana lainnya. Tujuan diadakan dan dilaksanakannya pidana mati supaya masyarakat memperhatikan bahwa pemerintah tidak menghendaki adanya gangguan terhadap ketentaraman yang sangat ditakuti oleh umum. (Djamali, 2005: 187)

Sebagai salah satu jenis pidana, pidana mati telah dikenal sejak zaman Romawi, Yunani, Jerman. (Prasetyo, 2012: 117) Pidana mati adalah pidana yang 
terberat dari semua ancaman pidana yang ada. (Marpaung, 2005: 104) Pidana mati merupakan pidana yang dijatuhkan terhadap orang berupa pencabutan nyawa berdasarkan putusan pengadilan yang berkekuatan hukum tetap. (Hamzah, 2008: 120)

Berdasarkan sejarah pidana mati bukanlah jenis pidana yang baru di Indonesia. Pidana ini telah dikenal sejak zaman kerajaan-kerajaan, hal ini dapat dibuktikan dengan memperhatikan jenisjenis pidana menurut hukum adat atau hukum para raja dahulu, misalnya:

1. Mencuri dihukum potong tangan

2. Pidana mati dilakukan dengan memutilasi, memukul kepala (sroh), dipenggal dan kemudian kepalanya ditusuk dengan kayu (tanjir), dan sebagainya. (Soesilo, t,th.: 14)

Pada awalnya WvS menentukan bahwa eksekusi pidana mati dilakukan dengan cara digantung. Kemudian berdasarkan Staatsblad 1945 Nomor 123 yang dikeluarkan oleh pemerintah Belanda, pidana mati dijatuhkan dengan cara ditembak mati. Hal ini diperkuat dengan Penetapan Presiden Nomor 2 Tahun 1964, Lembaran Negara 1964 Nomor 38 kemudian ditetapkan menjadi Undang-undang nomor 5 Tahun 1969 yang menetapkan bahwa pidana mati dijalankan dengan cara menembak mati terpidana. Dalam hal ini eksekusi harus dihadiri Jaksa (Kepala Kejaksaan Negeri) sebagai eksekutor dan secara tekhnis pelaksaan eksekusi dilakukan oleh regu tembak kepolisian. (Marpaung, 2005: 104)

Undang-Undang Nomor 2 / Pnps/ 1964/ Yaitu Penpres Nomor 2 Tahun 1964 (LN 1964 Nomor 38) yang ditetapkan menjadi undang-undang dengan undangundang nomor 5 Tahun 1969 tentang Tata
Cara Pelaksanaan Pidana Mati Yang Dijatuhkan Oleh Pengadilan Di Lingkungan Peradilan Umum Dan Militer menegaskan bahwa :

Pasal 1: Dengan tidak mengurangi ketentuan-ketentuan hukum acara pidana yang ada tentang penjalanan putusan pengadilan, maka pelaksanaan pidana mati, yang dijatuhkan oleh pengadilan di lingkungan peradilan umum atau peradilan militer, dilakukan dengan ditembak sampai mati.

Eksekusi terhadap terpidana mati haruslah dilaksanakan setelah putusan pengadilan yang dijatuhkan padanya berkekuatan hukum tetap dan kepada terpidana telah diberikan kesempatan untuk mengajukan grasi kepada Presiden. Eksekusi dapat dilaksanakan dengan terlebih dahulu melalui fiat executie (Pernyataan setuju untuk dijalankan). (Kansil, t,th.: 92)

Sistem pemidanaan menempatkan pidana mati menurut penulis itu dapat dilihat dari tujuan pemidanaan pidana mati. Tujuan pemidanaan dari pidana mati ini penulis analisis berdasarkan teori absolut. Menurut teori absolut, pidana adalah suatu hal yang mutlak harus dijatuhkan terhadap adanya suatu kejahatan. Muladi dan Barda Nawawi Arief berpendapat bahwa "pidana merupakan akibat mutlak yang harus ada sebagai suatu pembalasan kepada orang yang melakukan kejahatan. Jadi dasar pembenaran dari pidana terletak pada adanya atau terjadinya kejahatan itu sendiri". (Muladi dan Arief, 2005: 10) Hal ini senada dengan yang disampaikan oleh Andi Hamzah bahwa pidana adalah hal yang mutlak diberikan sebagai 
pembalasan terhadap suatu kejahatan. (Hamzah, 1993: 26)

Teori ini menganggap bahwa hukuman yang diberikan kepada sipelaku tindak pidana menjadi suatu pembalasan yang adil terhadap kerugian yang diakibatkannya, penjatuhan pidana pada dasarnya penderitaan pada penjahat dibenarkan karena penjahat telah membuat penderitaan bagi orang lain. (Prasetyo dan Barkatullah, 2005: 90)

Teori absolut ini memandang bahwa pemidanaan merupakan pembalasan atas kesalahan yang telah dilakukan, jadi berorientasi pada perbuatan dan terletak pada kejahatan itu sendiri. Pemidanaan diberikan karena si pelaku harus menerima sanksi itu demi kesalahannya. Menurut teori ini, dasar hukuman harus dicari dari kejahatan itu sendiri, karena kejahatan itu telah menimbulkan penderitaan bagi orang lain, sebagai imbalannya (vergelding) si pelaku harus diberi penderitaan. (Marpaung, 2005: 105)

Penjatuhan hukuman terhadap pelaku tindak pidana ini merupakan suatu hal yang memang sengaja ditimpakan karena diyakini juga mempunyai manfaat yang berbeda-beda. (Sahetapy, 1982: 201) Namun, Andi Hamzah lebih tegas menyatakan bahwa "pidana secara mutlak ada, karena dilakukan suatu kejahatan dan tidaklah perlu memikirkan manfaat dijatuhkannya pidana tersebut". (Hamzah, 1993: 26) Pendapat ini terkesan lebih tegas dari pernyataan sebelumnya karena penjatuhan pidana itu terlepas dari manfaat yang akan ditimbulkannya.

Jadi teori absolut merupakan pendekatan yang tepat dalam menganalisis eksistensi pidana mati di
Indonesia. Teori absolut atau retributif sebagai salah satu batu uji dalam mengukur penerapan pidana mati dalam sistem pemidaan yang secara otomatis akan memberikan tindakan preventif bagi masyarakat agar tidak melakukan tindak pidana yang akan diancam dengan pidana mati. Relevansi antara teori absolut dengan urgensi pidana mati di Indonesia yaitu dapat tercapainya keadilan, kemanfaatan serta kepastian hukum dalam penegakan hukum pidana scara komprehensif.

\section{Urgensi Pidana Mati}

Urgensi pidana mati di Indonesia juga dapat dianalisis dari teori tujuan hukum. Meski banyak pihak berpendapat bahwa masalah tujuan hukum adalah kajian filsafat hukum, namun Rusli Effendi dan kawan-kawan menjelaskan bahwa tujuan hukum dapat dikaji dari tiga sudut pandang yaitu: (Effendi dkk, 1991: 79)

1. Dari sudut pandang ilmu hukum normatif, tujuan hukum dititikberatkan pada segi kepastian hukum.

2. Dari sudut pandang filsafat hukum, maka tujuan hukum dititkberatkan pada keadilan.

3. Dari sudut pandang sosiologi hukum, maka tujuan hukum dititikberatkan pada segi kemanfaatan.

Dengan gambaran yang demikian membawa kita pada tiga nilai dasar hukum yang dikemukakan oleh Gustav Radbruch yaitu keadilan, kemanfaatan dan kepastian hukum. Meski diharapkan bahwa putusan hakim hendaklah merupakan resultante dari ketiga hal tersebut, namun dalam praktiknya hal itu 
sulit terjadi. Bahkan seringkali terjadi adalah sebaliknya, bahwa antara ketiganya terjadi ketegangan atau pertentangan. Dalam satu peristiwa, jika hakim harus memutus dengan adil, kepastian hukum terpaksa harus dikorbankan. Atau sebaliknya, demi kepastian hukum, keadilan tidak tercapai karena hukum yang sudah ada tidak sesuai lagi dengan rasa keadilan dalam masyarakat. (Agustina, 2014: 25)

Jika terjadi kondisi seperti itu, maka menurut Radbruch jalan keluarya adalah dengan menggunakan asas oportunitas, yang mengatakan bahwa jika harus diurutkan dari ketiga hal tadi, maka urutannya adalah keadilan, kemanfaatan dan kepastian hukum. Keadilan sebagai tujuan hukum sudah dibicarakan sejak zaman filsafat Yunani Kuno. Dalam lintasan sejarah filsafat hukum, keadilan merupakan substansi utama yang menjadi kajian semua aliran dalam filsafat hukum. (Agustina, 2014: 26)

Aliran Hukum Alam (Natural Law), hakikat dari ajaran hukum alam memandang bahwa hukum alam harus dipelihara oleh manusia untuk mencapai tujuan. Sehubungan dengan perlunya kesadaran atas posisi manusia untuk menyesuaikan dengan kepentingan atau tatanan normatif yang terdapat pada alam tersebut, maka tolok ukur aliran hukum alam terhadap esensi hukum, terletap berorientasi pada kepentingan alam yaitu kebaikan. Hakikat ini merupakan aturan alam semesta yang diciptakan oleh Tuhan dalam abadi-Nya, sehingga norma-norma dasar pada aliran hukum alam bersifat kekal, abadi dan universal. (Erwin, 2013: 141)

Sebaliknya dengan aliran positivis yang dipelopori oleh John Austin, berpandangan bahwa hukum itu harus dapat dilihat dalam ketentuan undangundang, karena hanya dengan itulah ketentuan hukum itu dapat diverifikasi. Adapun yang di luar Undang-Undang tidak dapat dimasukkan sebagai hukum karena hal itu berada di luar hukum. Hukum harus dipisahkan dengan moral, walaupun kalangan positivisme mengakui bahwa fokus mengenai norma hukum sangat berkaitan dengan disiplin moral, teologi, sosiolgi dan politik yang mempengaruhi perkembangan sistem hukum. Moral hanya dapat diterima dalam sistem hukum apabila diakui dan disahkan oleh otoritas yang berkuasa dengan memberlakukannya sebagai hukum. Oleh karenanya suatu hukum bisa saja tidak adil, namun tetap hukum karena dikeluarkan oleh penguasa. (Ali, 2002: 265)

Pada hakikatnya karakter hukum adalah keadilan, sebagaimana dilakukan oleh Cicero dan pemikir zaman abad pertengahan. Namun mustahil pula untuk mengidentikkan hukum dengan keadilan, sebagaimana dikehendaki oleh Hobbes dan kalangan positivis agar kita melaksanakannya. Keadilan dapat dianggap sebagai sebuah gagasan, atau sebuah realitas absolut sebagaimana dilakukan oleh Plato dan Hegel yang mengasumsikan bahwa pengetahuan dan pemahaman tentangnya hanya bisa didapatkan secara parsial dan melalui upaya filosofis yang sangat sulit. Namun keadilan sebagai tujuan hukum merupakan suatu keadaan yang harus diwujudkan oleh hukum, dengan berbagai upaya dinamisasi dari waktu kewaktu. (Agustina, 2014: 27)

Dari perbedaan tentang apa yang merupakan hukum menurut aliran 
hukum alam dan positivisme, maka dapat dilihat adanya perbedaan prioritas tujuan hukum. Jika aliran hukum alam mengutamakan keadilan sebagai tujuan hukum, maka positivisme mempertimbangkan kepastian hukum sebagai tujuan hukum. Dari paradigma positifis, keadilan memang merupakan tujuan hukum, tetapi relativitas keadilan itu sering mengaburkan unsur lain yang juga penting yaitu kepastian hukum.

Keadilan menurut aliran hukum alam adalah bila seseorang memberikan kepada orang lain apa yang menjadi haknya dan tidak merugikan orang lain. Menurut Aristoteles keadilan harus difahami dengan pengertian kesamaan, yaitu kesamaan numerik dan kesamaan proporsional. Kesamaan numerik adalah mempersamakan setiap manusia sebagai suatu unit, yang pada saat sekarang difahami sebagai kesamaan kedudukan setiap warga negara di depan hukum (equality before the law). Sedangkan kesamaan proporsional adalah bertindak proporsional dan tidak melanggar hukum. (Agustina, 2014: 27)

Selain itu Aristoteles juga mengemukakan tentang keadilan distributif dan keadilan korektif. Keadilan distributif lebih ditujukan pada kesamarataan dalam memberikan pemenuhan hak kepada setiap orang. Sementara keadilan korektif, merupakan usaha membetulkan suatu yang salah. Jika suatu peraturan dilanggar atau seseorang melakukan kesalahan, maka keadilan korektif berusaha memberikan kompensasi yang memadai kepada pihak yang dirugikan. Apabila kejahatan telah dilakukan, maka hukuman yang sepantasnya perlu diberikan kepada pelaku kejahatan. (Agustina, 2014: 28)

Berkenaan dengan berbagai macam tentang keadilan, Thomas Aquinas memberikan pembedaan antara justitia distributiva dan justitia commutativa, yang merupakan varian dari asas persamaan. Jadi prinsip pertama keadilan adalah perwujudan impartialitas dengan perlakuan yang sama terhadap pribadipribadi serta bebas prasangka. Selain dari distributive justice dan commutative justice, juga dikenal substantive justice dan prosedural justice. Subtantive justice terkait dengan substansi dari persoalan dalam hukum, yaitu masalah hak, kewajiban, kekuasaan, pertanggungjawaban dan lainlain. Sementara prosedural justice berkenaan dengan prosedur yang diterapkan dalam penyelesaian suatu konflik hukum, atau pengambilan suatu keputusan dalam persoalan hukum.

Suatu hal yang penting untuk dipahami dalam kaitan keadilan sebagai tujuan hukum adalah apa yang dikatakan oleh Kelsen dalam bukunya What is justice ? Dia mengatakan bahwa justice is a quality which relates not to content of a positive order, but to its apllication. Jadi keadilan itu ada pada penerapan hukum, manakala dalam praktik penegakan hukum terdapat persamaan perlakuan bagi mereka yang melakukan tindak pidana yang sama atau dapat dipersamakan. Begitupun kesimpulan dari Carl Joachim Friedriech bahwa keadilan hanya bisa dipahami jika diposisikan sebagai keadaan yang hendak diwujudkan oleh hukum. (Agustina, 2014: 27)

Mengacu pada teori keadilan, maka teranglah bahwa pidana mati sebagai sanksi pidana yang ada dalam sistem 
pemidanaan mempunyai peran yang sangat urgent. Yaitu memberikan keadilan kepada korban dan keluarga secara khusus dan kepada masyarakat pada umumnya. Keadilan yang ingin dicapai dengan pidana mati adalah keadilan yang bersifat substantif dan keadilan bersifat prosedural. Keadilan substantif salah satunya terkait dengan substasi persoalan hukum, yaitu persoalan hukum terpidana sehingga dengan segala pertimbangan majelis hakim terpidana dijatuhi pidana mati. Sementara keadilan prosedural adalah rangkaian prosedur yang diterapkan dalam penyelesaian suatu konflik hukum.

Urgensi pidana mati selanjutnya akan memberikan ketertiban karena harmonisasi sosial di tengah-tengah masyarakat telah terpulihkan. Artinya yang membutuhkan upaya restoratif sesungguhnya adalah masyarakat yang harmonisasi sosialnya terganggu oleh kejahatan tersebut. Dengan demikian pidana mati sebagai upaya untuk merestorasi disharmonisasi sosial itu. (Efendi, 2016: 100)

Berbanding terbalik dengan argumentasi yang berlindung di balik restorative justice yang semata-mata melihat pelaku kejahatan yang diancam dengan pidana mati. Pandangan ini telah mengabaikan fakta bahwa setiap kejahatan sesungguhnya serangan terhadap harmonisasi sosial dalam masyarakat, yang berarti pula bahwa setiap kejahatan menimbulkan luka berupa disharmonisasi sosial pada masyarakat.

Makin tinggi kualitas kejahatan, makin tinggi pula kualitas disharmonisasi sosial yang ditimbulkan. Sehingga pertanyaan yang muncul kemudian adalah mungkinkah harmonisasi sosial dalam masyarakat dipulihkan dengan merestorasi pelaku kejahatan. Maka pidana mati yang dijatuhkan haruslah dilihat sebagai upaya untuk mengembalikan harmoni sosial yang terganggu akibat tindak pidana tersebut dan pada akhirnya akan terciptanya ketertiban dalam masyarakat. (Efendi, 2016: 100)

\section{Hasil Penelitian}

\section{Kedudukan Pidana Mati dalam Konstitusi}

Dalam kedudukannya sebagai pengawal konstitusi, Mahkamah Konstitusi melalui putusannya Nomor 2-3/PUUV/2007 memberikan titik akhir akan perdebatan pidana mati selama ini k’arena konstitusionalitas pidana mati semakin dikukuhkan. Sekalipun putusan tersebut dalam konteks tindak pidana narkotika, namun demikian putusan ini menjadi dasar pemikiran yang genuine tentang kedudukan pidana mati dan konstitusionalitasnya di Indonesia. (http:/ / majalahprosekutor.com)

Jaminan perlindungan konstitusional atas hak hidup yang diatur dalam landasan konstitusional Republik Indonesia Pasal 28A dan 28I ayat (1) Undang-Undang Dasar Republik Indonesia Tahun 1945 dipahami sebagai non-derogable rights, yaitu:

Bahwa hak untuk hidup, hak untuk tidak disiksa, hak kemerdekaan pikiran dan hati nurani, hak beragama, hak untuk tidak diperbudak, hak untuk diakui sebagai pribadi di hadapan hukum dan hak untuk tidak dituntut atas dasar hukum yang berlaku surut adalah hak asasi manusia 
yang tidak dapat dikurangi dalam keadaan apapun.

Artinya jika difahami hanya sebatas pada ketentuan Pasal 28 I ayat (1) tersebut di atas, maka hak hidup merupakan hak mutlak yang tidak dapat dikurangi dalam kondisi dan alasan apapun. Namun secara sistematis tentunya tidak dapat memahami ketentuan secara parsial, melainkan harus difahami secara komprehensif termasuk juga terhadap pasal 28J ayat (2) yang menyatakan:

Dalam menjalankan hak dan kebebasannya, setiap orang wajib tunduk kepada pembatasan yang ditetapkan dengan undang-undang dengan maksud sematamata untuk menjamin pengakuan serta penghormatan atas hak dan kebebasan orang lain dan untuk memenuhi tuntutan yang adil sesuai dengan pertimbangan moral, nilai-nilai agama, keamanan dan ketertiban umum dalam suatu masyarakat yang demoktratis.

Berdasarkan pasal 28J ayat (2) tersebut, diberikan pembatasan yang diartikan bahwa hak untuk hidup tidak bersifat mutlak, sehingga pidana mati tidak bertentangan dengan konstitusi. Pemahaman hak untuk hidup sebagai salah satu non-derogable rights yang dipahami dalam pengertian instrument HAM internasional, bahwa Pasal 6 International Convenan On Civil and Political Rights (ICCPR) ayat (2) masih memperbolehkan diterapkannya pidana mati untuk the most serious crime. (Putusan Mahkamah Konstitusi, 2007: 456)

Bahwa menurut sejarah penyusunan Pasal 28I UUD 1945, yang pada intinya menerangkan bahwa ketika merumuskan Bab XA tentang Hak Asasi Manusia rujukannya atau yang melatarbelakanginya adalah Ketetapan MPR Nomor XVII/MPR/1998. Dari ketetapan MPR tersebut kemudian lahir Undang-Undang Nomor 39 Tahun 1999 tentang Hak Asasi Manusia. Semangat keduanya adalah sama-sama menganut pendirian bahwa hak asasi manusia bukan tanpa batas. Selanjutnya bahwa semangat yang sama juga terdapat dalam pengaturan tentang hak asasi manusia dalam UUD 1945, yaitu bahwa hak asasi manusia bukanlah sebebas-bebasnya melainkan dimungkinkan untuk dibatasi sejauh pembatasan itu ditetapkan dalam undang-undang. (Lubis dan Lay, 2009: 354)

Semangat inilah yang melahirkan Pasal 28J UUD 1945. Pembatasan sebagaimana tertuang dalam Pasal 28J itu mencakup Pasal 28A sampai dengan Pasal 28I UUD 1945. Dari perspektif original instent, pembentuk UUD 1945, seluruh hak asasi manusia yang tercantum dalam Bab XA UUD 1945 keberlakuannya dapat dibatasi. Original intent pembentuk UUD 1945 yang menyatakan bahwa hak asasi manusia dapat dibatasi juga diperkuat oleh penempatan Pasal 28J sebagai Pasal penutup dari seluruh Pasal yang mengatur tentang hak asasi manusia dalam Bab XA UUD 1945 tersebut. (Lubis dan Lay, 2009: 355)

Berdasarkan penafsiran sistematis (sistematische interpretatie), hak asasi manusia yang diatur dalam Pasal 28A sampai dengan Pasal 28I UUD 1945 tunduk pada pembatasan yang diatur dalam Pasal 28J UUD 1945. Sistematika pengaturan hak asasi manusia sejalan dengan sistematika pengaturan dalam Universal Declaration of Human Rights yang juga menempatkan Pasal penutup, yaitu 
Pasal 29 Ayat (2) yang berbunyi : (United Nations Universal Declaration Human Rights, 1948: 6)

In the exercise of his rights and freedoms, everyone shall be subject only to such limitations as 412 are determined by law solely for the purpose of securing due recognition and respect for the rights and freedoms of others and of meeting the just requirements of morality, public order and the general welfare in a democratic society.

Dengan demikian apabila Pasal 28 I ayat (1) saja yang dianalisis tanpa mengkorelasikan dengan Pasal lain akan menimbulkan pemahaman bahwa konstitusi melarang pidana mati. Tetapi jika mencermati Pasal 28 I ayat (1) kemudian dikorelasikan dengan ketentuan Pasal 28 J ayat (2), maka dapat ditarik suatu kesimpulan bahwa hak untuk hidup, hak untuk tidak disiksa, hak kemerdekaan pikiran dan hati nurani, hak beragama, hak untuk tidak diperbudak, hak untuk diakui sebagai pribadi di hadapan hukum dan hak untuk tidak dituntut atas dasar hukum yang berlaku surut adalah hak asasi manusia yang tidak dapat dikurangi dalam keadaan apapun, tetapi pelaksanaan hak tersebut dapat dibatasi dan dihilangkan pelaksanaannya dengan syarat memenuhi persyaratan dalam Pasal $28 \mathrm{~J}$ ayat (2) UUD 1945. Sehingga penulis berpendapat bahwa pidana mati dalam sistem pemidanaan merupakan sanksi pidana yang masih sangat relevan untuk diaplikasikan yang mendasarkan pada ketentuan Ultymum Remedium sebagai upaya untuk menekan pertumbuhan kriminalitas.

\section{Qhisash dalam Ketentuan Fiqih Jinayah}

\section{Jarimah dan Uqubah (Tindak Pidana dan} Hukuman)

Tindak pidana dalam fiqih jinayah diikenal dengan istilah jarimah (Moeljatno, 1993: 55). Kata jarimah merupakan sinonim dari kata jinayat. Secara istilah diartikan sebagai perbuatan yang dilarang oleh syara' baik perbuatan itu merugikan jiwa, harta benda atau lainnya. Lebih khusus jarimah didefinisikan sebagai kejahatan-kejahatan yang melanggar hukum syara' dan pelakunya dikenakan hukuman. (Zahrah, t,th. : 29)

Figh jinayah atau hukum pidana Islam bersumber kepada Alquan, sunnah dan ijma'. Pada dasarnya figh jinayah sama pendiriannya dengan hukum positif dalam menetapkan perbuatan-perbuatan jarimah beserta pidananya yaitu memelihara kepentingan, ketenteraman, dan kelangsungan hidup masyarakat. (Syahrur, 2008: 16)

Jarimah dalam figh jinayah secara umum dikelompokan menjadi tiga jenis, meliputi:

1. Jarimah Hudud

Jarimah hudud adalah jarimah yang diancam dengan hukuman had, yaitu hukuman yang telah ditentukan oleh syara' dan merupakan hak Allah. Oleh karena hukuman had merupakan hak Allah maka hukuman tersebut tidak bisa digugurkan oleh perseorangan (korban atau keluarganya). Jarimah hudud ini dibagi menjadi tujuh macam, yaitu:
a. Jarimah zina
b. Jarimah qadzaf
c. Jarimah syurb al-khamr
d. Jarimah pencurian
e. Jarimah hirabah 
f. Jarimah riddah

g. Jarimah pembrontakan. (Muslich, 2005: $x)$

2. Jarimah qhisash dan diyat

Jarimah qhisash dan diyat adalah jarimah yang diancam dengan hukuman qhisash atau diyat. Baik qhisash maupun diyat kedua-duanya adalah hukuman yang sudah ditentukan oleh syara'. Perbedaannya dengan hukuman had adalah bahwa hukuman had merupakan hak Allah (hak masyarakat), sedangkan qhisash atau diyat merupakan hak manusia (individu). Di samping itu, perbedaan yang lain adalah qhisash atau diyat merupakan hak manusia maka hukuman tersebut bisa dimaafkan atau digugurkan oleh korban dan keluarganya, sedangkan hukuman had tidak bisa dimaafkan atau digugurkan. Muslich, 2005: x) Sementara diyat merupakan hukuman pokok bagi pembunuhan disengaja, pembunuhan menyerupai sengaja (diyat dan kifarat) dan pembunuhan tidak disengaja. (Hakim, 2000: 133)

3. Jarimah $t a^{\prime} z i r$

Jarimah ta'zir pada dasarnya
adalah hukuman yang belum
ditetapkan oleh syara' dan wewenang
untuk menetapkannya diserahkan
kepada ulil amri. (Muslich, 2005: xii)

\section{Qhisash}

1. Pengertian dan Dasar Hukum Qhisash

Qhisash adalah hukuman pokok bagi tindak pidana dengan objek jiwa atau anggota badan yang dilakukan dengan sengaja, seperti membunuh, melukai, menghilangkan anggota badan dengan sengaja. (Hakim, 2000: 125) Qhisash disyari'atkan berdasarkan Alquran, sunnah dan ijma'. Dasar hukum yang terdapat dalam Alquan salah satunya terdapat dalam surat alBaqarah ayat 178 , surat Al-Baqarah ayat 179, surat Al-Maidah ayat 45 serta beberapa hadis Nabi Muhammad Saw.

2. Syarat-Syarat Qhisash

Hukuman qhisash tidak dapat dilaksanakan apabila syarat-syaratnya tidak terpenuhi. Syarat-syarat tersebut meliputi syarat-syarat untuk pelaku, korban, perbuatan (tindak pidana) serta ahli warisnya.

a. Syarat-syarat pelaku yaitu pelaku harus mukalaf (baligh dan berakal), melakukan pembunuhan dengan sengaja, pelaku harus orang yang mempunyai kebebasan

b. Syarat-syatat korban yaitu korban harus orang yang dijamin keselamatannya oleh negara Islam, hendaknya korban seimbang dengan pelaku (yaitu Islam dan merdeka, dengan demikian seorang muslim tidak bisa di qhisash karena ia membunuh orang kafir, seorang merdeka tidak dapat di qhisash karena membunuh hamba).

c. Syarat untuk perbuatan yaitu untuk bisa diterapkannya qhisash bagi pelaku disyaratkan perbuatan pembunuhan harus perbuatan langsung. (Muslich, 2005: 151)

3. Pelaksanaan Hukuman Qhisash

a. Orang yang berhak melaksanakan qhisash dalam tindak pidana selain jiwa adalah korban itu sendiri, yaitu apabila telah baligh berakal. Apabila belum baligh maka yang berhak 
untuk melaksanakan qhisash adalah ahli waris.

b. Eksekusi qhisash yaitu jika vonis qishash telah ditetapkan dan semua syarat-syaratnya terpenuhi, maka ahli waris (wali) korban boleh segera melaksanakan qishash tanpa menundanunda waktu. Karena qishash adalah hak mereka. Namun jika pelaku adalah seorang perempuan yang sedang hamil, maka pelaksanaan ditunda sampai ia melahirkan. Bahkan pelaksanaannya harus ditunda sampai habis masa menyusui jika tidak ada orang lain yang menyusui bayinya. Eksekusi qhisash harus mendapat Izin penguasa, mayoritas ahli fiqih berpendapat bahwa tidak boleh melaksanakan qishash tanpa adanya izin dari penguasa, karena pentingnya masalah eksekusi qishash ini.

\section{Hal-hal yang Menggugurkan Qhisash}

a. Kematian pelaku pembunuhan, jika pelaku pembunuhan meninggal sebelum diqishas, maka gugurlah qhishas atas dirinya.

b. Pemberian maaf ahli waris (wali) korban, jika ahli waris (wali) korban memaafkan si pembunuh, maka berdasarkan kesepakatan para ulama, gugurlah hukum qishash. Karena ahli waris mempunyai dua hak atas orang yang membunuh saudaranya yaitu diyat atau qishash.

c. Perdamaian atas qhishas, para ahli fikih sepakat atas bolehnya kesepakatan damai antara pelaku pembunuhan dengan ahli waris (wali) korban. Kemudian si pelaku membayar kompensasi yang telah disepakati oleh keduanya. Dan itu tidak dibebankan atas Aqilah (keluarga besar pelaku), melainkan atas pelaku sendiri. Besar kompensasi tergantung kesepakatan antara wali korban dan si pelaku. Boleh dibayar kontan atau berangsur. Karena perdamaian berstatus ganti rugi. (Muslich, 2005: 160)

5. Diyat sebagai Pengganti Qhisash

Diyat sebagai pidana pengganti dari qhisash dapat dibedakan menjadi:

a. Diyat Mughalallazhah

Menurut jumhur ulama diyat mughalallazhah berlaku untuk pembuhan dengan sengaja apabila qhisash dimaafkan oleh keluarga korban serta berlaku bagi pembunuhan menyerupai sengaja. (Zuhaili, 1989: 304) Diyat Mughalallazah hanya berlaku apabila diyat tersebut dibayar dengan unta, sesuai dengan ketentuan syara' dan tidak berlaku dalam jenis yang lain seperti emas dan perak. Dengan ketentuan: (Audah, t,th.: 249)

1) Tiga puluh ekor unta higqah (unta betina berumur 3-4 tahun).

2) Tiga puluh ekor unta jadza'ah (unta betina berumur 4-5 tahun).

3) Empat puluh ekor unta khalifah (unta sedang bunting).

Pendapat tersebut di atas di dasarkan pada hadis Nabi yang diriwayatkan oleh Turmidzi dan Abu Dawud dari Amr ibnu Syu'aib bahwa Rasulullah bersabda yang artinya:

"diyat itu adalah tiga puluh ekor unta jadza'ah (umur 4-5 tahun), tiga puluh hiqqah (umur 3-4 tahun), dan 
empat puluh khalifah (unta yang sedang bunting)"

\section{b. Diyat Mukhafaffah}

Yaitu denda yang sifatnya ringan dengan membayar denda berupa 100 ekor unta terdiri 20 ekor hiqqah, 20 ekor jadz'ah, 20 ekor binta labun (unta betia umur lebih dari 2 tahun), 20 ekor ibnu labun (unta jantan berumur lebih dari 2 tahun) dan 20 ekor binta mukhod (unta betina bermur lebih 2 tahun) diyat mukhaffah diwajibkan atas pembunuhan bersalah dibayar oleh keluarga pembunuh dan diangsur 3 tahun tiap tahun sepertiganya. (Muslich, 2005: 171)

Dengan demikian, sungguh di dalam qhisash terdapat kedupan, yakni dengan qishahs sebagai detrance efect serta sebagai tidakan preventif bagi masyarakat luas untuk tidak melakukan tidakan yang sama. Dengan tidak melakukan perbuatan yang sama di sinilah kehidupan yang dimaksud oleh tujuan qhisash ini. Di samping itu juga bahwa qhisash sesungguhnya mengakomodir dua kepentingan, hak Allah dan hak korban serta keluargnya. Di mana hak Allah akan gugur jika keluarga memberikan pemaafan kepada terpidana. Sehingga hukum pidana Islam merupaka hukum pidana yang sangat menjunjung tinggi nilai-nilai humanisme.
Analisis Kajian Comparatif Pidana Mati dalam Sistem Pemidanaan di Indonesia dan Qhisash dalam Sistem Hukum Pidana Islam di Arab Saudi

Sebagai negara yang berdaulat, Indonesia dan Arab Saudi adalah negara yang masih menerapkan pidana mati dalam sistem hukum pidana. Eksistensi pidana mati di kedua negara ini dikarenakan pidana mati masih sangat dibutuhkan dalam rangka mencapai kebenaran materil. Selain itu pidana mati sebagai upaya terhadap penghormatan hak asasi manusia, karena pidana mati tidak akan dijatuhkan melainkan karena terpidana telah melakukan tindak pidana yang telah terlebih dahulu melanggar hak asasi orang lain, sehingga dipandang perlu untuk dijatuhi pidana mati.

Pidana mati yang ada di Indonesia maupun di Arab Saudi memiliki banyak persamaan yang menempatkan pidana mati sebagai ultimum remedium, yakni pidana yang dapat diterapkan manakala unsur-unsur pemidanaan itu telah terpenuhi. Sekalipun dipandang sebagai hak mendasar, namun hak asasi manusia patut mendapat pembatasan. Pembatasan itu dibenarkan manakala hak hidup orang banyak dijadikan sebagai prioritas dari pada hak hidup perseorangan.

Pidana Islam Sebagaimana dianut oleh Arab Saudi membenarkan penerapan pidana mati karena adanya prinsip pembalasan yang setimpal, maka hal demikian harus dilihat secara hernemeutik yaitu teks yang diturunkan dalam konteks tingkat kemampuan dan perkembangan masyarakat manusia saat itu dalam mengelola kehidupan bersama yang tertip menurut hukum Pidana Islam dan dapat 
dipahami oleh tingkat komplesitas kelembagaan yang ada pada saat itu. Akan tetapi Allah Swt memberi manusia akal budi dan pengetahuan tentang hal yang baik dan buruk untuk mengembangkan diri dan kemanusiaan.

Dari kajian perbandingan ini penulis menganalisis bahwa keberadaan Qhisash yang ada di Arab Saudi lebih memberikan kepastian dan kemanfaatan hukum, yaitu penerapan qhisash terbukti memberikan manfaat dan kebahagiaan bagi penganut sistem hukum Islam. Di mana adanya keseimbangan antara Hak Allah dan hak manusia, di mana qhisash akan gugur jika pelaku telah dimaafkan oleh korban (untuk jarimah selain jiwa) dan keluarga untuk tindak pidana atas jiwa. Artinya adalah Allah lebih mendahulukan hak manusia, jika tidak mendapatkan pemaafan maka terpidana baru akan di qhisash. Hal ini adalah bukti konkrit bahwa hukum pidana Islam adalah hukum yang sangat humanisme, sehingga di dalam qhisash sungguh terdapat kehidupan bagi mereka yang memikirkannya karena detrance effect.

Indonesia sebagai negara civil law, adalah suatu keniscayaan untuk mengakomodir qhisash dalam sistem pemidanaannya. Terlebih dengan telah diterapkan hukum pidana mati masih dinilai belum efektif untuk menekan angka pertumbuhan tindak pidana, sehingga menurut penulis tidak ada salahnya untuk mencoba terlebih dahulu memberlakukan qhisash untuk beberapa tindak pidana yang tergolong extra ordinary crime. Tawaran ini penulis dasarkan atas Indonesia yang notabenenya Eropa Kontinental namun juga mengakomodir sistem hukum Anglo Saxon, artinya bahwa tidak tertutup kemungkinan untuk mengakomodir sistem hukum Islam, qhisash khususnya dalam sistem hukum pidana di Indonesia.

Mengintegrasikan qhisash dalam sistem hukum pidana di Indonesia dapat dilakukan dengan jalan pembaruan hukum pidana, yaitu membuat atau memberlakukan suatu peraturan perundang-undangan untuk mengatur tindak pidana yang dapat diancam pidana mati. Muladi memberikan metode pendekatan yaitu: (Muladi, t,th. :30)

\section{Evolutionary Approach}

Dengan metode ini kriminalisasi kejahatan dilakukan dengan cara perbaikan, penyempurnaan dan amandemen terhadap peraturanperaturan yang sudah lama di dalam KUHP. Terkait dengan memberlakukan qhisash dalam sistem pemidanaan di Indonesia, kita dapat memperbaiki, menyempurnakan atau mengamandemen secara kompehensif seluruh legal substance (Basuki, 2001: 7) yang mencantumkan sanksi pidana mati dirubah secara substansi kepada qhisash. Pemberlakukan ini di dasarkan atas asas prefensi umum yaitu lex specialis derogat legi generali, yang diberlakukan khusus bagi umat muslim yang ada di Indonesia. Bukankan $90 \%$ penduduk Indonesia adalah umat muslim, sehingga tidak berasalan untuk tidak menerpkan sistem hukum pidana Islam bagi para pemeluknya, sebagaimana memberlakukan secara parsial hukum perdata Islam bagi pemeluknya di negeri ini.

\section{Global Approcah}

Metode ini dilakukan dengan membuat peraturan tersendiri di luar ketentuan hukum pidana yang sudah ada. 
Menurut hemat penulis, hal ini adalah jalan yang lebih terbuka untuk membentuk iuc constituendum melalui jalan program legislasi nasional. Merumuskan norma baru dengan ketentuan bagi umat Islam yang melakukan tindak pidana yang diancam dengan pidana mati, maka qhisash berlaku atasnya sebagaimana memberlakukan hukum perdata Islam di Indonesia.

\section{Comppromise Approach}

Merode ini dilakukan dengan cara menambah bab tersendiri dalam KHUP. Menurut penulis, metode ini akan menimbulkan banyak persoalan untuk mengakomodir qhisash, karena melakukan penambahan $\mathrm{BAB}$ tersendiri dalam ketentuan KUHP maupun ketentuan hukum pidana khusus yang sudah ada bukanlah perkara mudah.

\section{PENUTUP}

Pada bagian ini legal standing penulis yakni hakikat pidana mati maupun qhisash bukan sebagai ketentuan pidana yang melanggar hak asasi dari terpidana, karena perbuatan terpidana telah terlebih dahulu tidak lagi memperhatikan aspek kehidupan yang berprikemanusiaan dan kehidupan yang penuh dengan keadilan sosial. Dengan menjatuhkan pidana mati akan memberikan keadilan secara subtantif kepada pelaku serta keluarga korban. Penjatuhan pidana mati merupakan upaya restorative justice dalam lingkungan. Di mana dengan menjatuhkan pidana mati akan merestorasi disharomisasi sosial yang rusak akibat tejadinya tindak pidana.
Sepanjang Undang-undang masih mengatur tentang pidana mati dalam sistem pemidanaan, maka pidana mati adalah sanksi pidana yang konstitusional, terlebih dalam hukum pidana Islam, ketentuan qhisash merupakan sanksi pidana yang datangnya dari ketentuan Allah, walaupun berbeda sistem hukum baik qhisash maupun pidana mati yang ada di Indonesia adalah sanksi pidana yang relevan untuk diterapkan secara univesal.

\section{DAFTAR KEPUSTAKAAN}

Adi, Rianto. 2004. Metodologi Penelitian Sosial dan Hukum. Jakarta: Granit.

Agustina, Shinta dkk. 2015. Obstruction of Justice Tindak Pidana Menghalangi Proses Hukum Dalam Upaya Pemberantasan Korupsi. Jakarta: Themis Books. 2014. Asas Lex Specialis Derogat Legi Generali Dalam Penegakan Hukum Pidana. Jakarta: Themis Books.

Ali, Achmad. 2002. Menguak Tabir Hukum, Suatu Kajian Filosofis dan Sosiologis. Cet. II, Jakarta: Penerbit Gunung Agung.

Arief, Barda Nawawi. 2003. Perbandingan Hukum Pidana. Jakarta: PT. Raja Grafindo Persada.

Audah, Abd Al-Qadir. tth. At-Tasyri' AlJinaiy Al Islami. Beirut: Dar Al-Kitab Al-Arabi.

Djamali, R. Abdoel. 2005. Pengantar Hukum Indonesia (Edisi Revisi). Jakarta: Rajawali Pers. 
Efendi, Roni. 2016. Kedudukan Pidana Mati Dalam Sistem Pemidanaan. Tesis, Padang: Universitas Andalas.

Effendi, Rusli, Achmad Ali dan Poppy Andi Lolo. 1991. Teori Hukum. Makasar: Hasanuddin University Press.

Erwin, Muhammad. 2013. Filsafat Hukum Refleksi Kritis Terhadap Hukum. Jakarta: PT. Raja Grafindo Persada.

Friedman, Lawrence M. 2001. American Law An Introduction Second Edition. Sebagaimana diterjemahkan oleh Wishnu Basuki, Hukum Amerika. Jakarta: PT. Tatanusa.

Hakim, Rahmat. 2000. Hukum Pidana Islam (Figh Jinayah). Bandung: CV Pustaka Setia.

Hamzah, Andi. 1993. Sistem Pidana dan Pemidanaan di Indonesia. Jakarta: Pradnya Paramita.

2008. Terminologi Hukum Pidana, Jakarta: Sinar Grafika.

Hanitijo, Ronny. 1993. Metode Penelitian Hukum. Jakarta: Ghalia Indo.

Kansil, C.S.T dan Kansil, Christine S.T. tth. Pokok-Pokok Hukum Pidana (Hukum Pidana Tiap Orang). Jakarta: PT. Pradnya Paramitha.

Lubis, Todung Mulya dan Aexander Lay. 2009. Kontroversi Hukuman Mati: Perbedaan Pendapat Hakim Konstitusi. Jakarta: Kompas Penerbit Buku.

Mahmud, Peter. 2009. Pengantar Ilmu Hukum. Jakarta: Prenada Media Group.
Marpaung, Leden. 2005. Asas, Teori, Praktik Hukum Pidana. Jakarta: Sinar Grafika.

Moeljatno. 1993. Asas-Asas Hukum Pidana. Jakarta: Rineka Cipta.

Muhammad, Abdulkadir. 2004. Hukum dan Penelitian Hukum. Bandung: PT. Citra Aditya Bakti.

Muladi dan Barda Nawawi Arief. 2005. Teori-Teori dan Kebijakan Pidana. Bandung: Alumni.

Proyeksi Hukum Pidana Materil Indonesia di Masa Datang, Pidato Pengukuhan Guru Besar Hukum Pidana, Semarang: Fakultash Hukum Universitas Diponegoro.

Muslich, Ahmad Wardi. 2005. Hukum Pidana Islam. Jakarta: Sinar Grafika.

2006. Pengantar dan Asas Hukum Pidan Islam Figh Jinayah, Jakarta. Sinar Grafika.

Poerwodarminto, Bdk. W. J. S. 1983. Kamus Umum Bahasa Indonesia. Jakarta: Pusat Pembinaan Pengembangan Bahasa Indonesia Departemen Pendidikan dan Kebudayaan.

Prasetyo, Teguh. 2012. Hukum Pidana, Jakarta: PT. Raja Grafindo Persada.

dan Abdul Halim Barkatullah. 2005. Politik Hukum Pidana (Kajian Kebijakan Kriminalisasi dan Dekriminalisasi). Jakarta: Pustaka Belajar.

Sahetapy, JE. 1982. Suatu Studi Khusus Mengenai Ancaman Pidana Mati Terhadap Pembunuhan Berencana. Jakarta: Rajawali. 
Soejono dan Abdurrahman. 2003. Metode Penelitian Hukum. Jakarta: Rineka Cipta.

Soekanto, Soerjono. 1986. Pengantar Penelitian Hukum. Jakarta: UI Press. 2006. Penelitian Hukum Normatif. Jakarta: PT. Raja Grafindo Persada.

dan Sri Mamudji. 2009.

Penelitian Hukum NormatifSuatu Tinjauan Singkat. Cetakan ke - 11. Jakarta: PT Raja Grafindo Persada.

Soesilo, R.. tth. Pokok-Pokok Hukum Pidana Peraturan Umum dan Delik-Delik Khusus. Bogor: Pelitea.

Sugono, Bambang. 2001. Metode Penelitian Hukum. Jakarta: Raja Grafindo Persada.

Suryabrata, Sumardi. 2006. Metodologi Penelitian. Jakarta: PT. Raja Grafindo Persada.

Syahrur, Muhammad. 2008. Limitasi Hukum Pidana Islam. Semarang: Walisongo Press.

Van Hoecke, M. (ed). 2011. Methodologies of Legal Research. Oxford: Hart Publishing.

Waluyo, Bambang. 2002. Penelitian Hukum dalam Praktik. Jakarta: Sinar Grafika.

Zahrah, Muhhamad Abu. Tth. Al-Jarimah. Mesir: Dar Al-Fikr Al-Arabi.

Zed, Mestika. 2007. Metode Penelitian Kepustakaan. Jakarta: Yayasan Obor Indonesia.

Zuhaili, Wahbah. 1989. Al-Figh Al Islami wa Adillatuhu, Juz VI, Dar Al-Fikr, Damaskus.

\section{Jurnal}

Humulhaer, Siti. 2011. Penerapan Hukuman Mati di Indonesia Ditinjau Dari Filsafat Hukum. Jurnal Supremasi Hukum, Volume 7.

Yunus, Yutrisa. 2013. Analisis Konsep Restorative Justice Melalui Sistem Diversi Dalam Sistem Peradilan Pidana Anak di Indonesia, Jurnal Rechtsvinding. Volume 2 Nomor 2, Agustus.

\section{Undang-Undang}

Undang-Undang Nomor 5 Tahun 1969 tentang Tata Cara Pelaksanaan Pidana Mati Yang Dijatuhkan Oleh Pengadilan Di Lingkungan Peradilan Umum Dan Militer

Kitab Undang-Undang Hukum Pidana dan Kitab Undang-Undang Hukum Acara Pidana, Bandung, Citra Umbara, 2006.

Tap MPR Nomor XVII/MPR/1998 Tentang Hak Asasi Manusia.

United Nations Universal Declaration Human Rights 1948.

Putusan Mahkamah Konstitusi, Nomor 23/PUU-V/2007, hlm. 456.

\section{Website}

Purba, Nelvita. Konstitusionalitas Hukuman Mati di Indonesia, dalam http://majalahprosekutor.com diakses pada 20 September 2015. 
